\title{
Gender Differentials In Educated People's Perceptions Regarding Anti Women Social Practices In Pakistan
}

\author{
Naima Tabassum \\ Area Study Center \\ University of Sindh \\ Tabassum Afzal \\ Department of Education \\ University of Karachi \\ Huma Tabassum \\ Government Degree College Latifabad, Hyderabad
}

\begin{abstract}
This research aims to explore gender differentials in perceptions regarding several social and cultural practices causing harm to the status of women in Pakistan. The six social practices focused in this research include Dowry, Watta Satta, Walwar, Swara, Vani and Marriage with Quran. The research is designed as exploratory cross sectional quantitative research. The data has been collected through survey of a randomly selected sample of 347 educated men and women in Sindh with the help of a six items, five point Likert scale, to explore people's perceptions regarding different socio-cultural practices. The scale has two sub scales, each including three items, to assess perceptions regarding social practices perceived as crime and their potential for causing victimization of women in Pakistan. It is inferred from the t-test results that there is statistically significant difference exists between educated men and women's mean scores acquired on one main scale and two sub scales used to assess perception regarding social practices, their criminal nature, and potential for victimization of women in Pakistan.
\end{abstract}

Keywords: Social Practices, Watta Satta, Dowry, Walwar, Vani, Swara, Marriage with Quran, Pakistan.

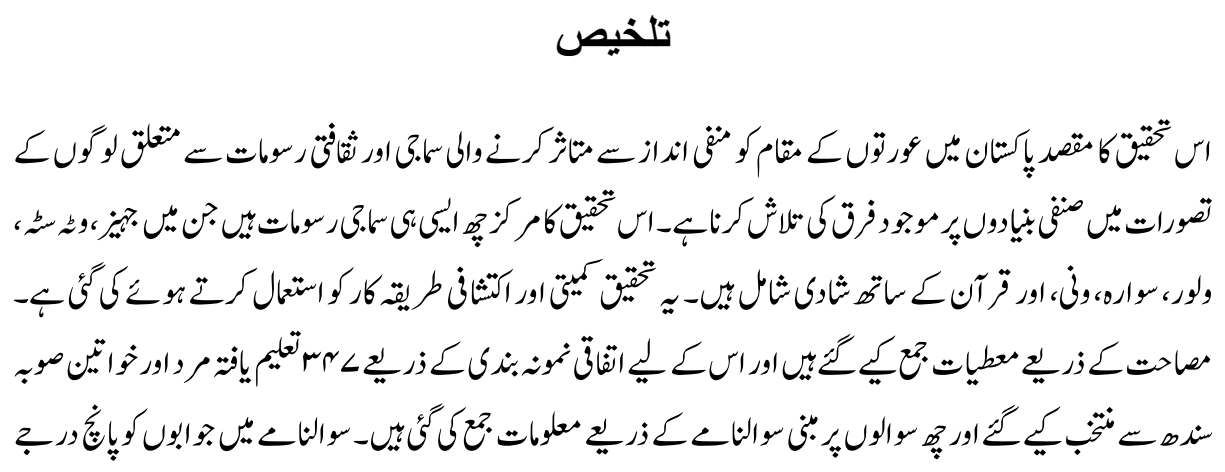




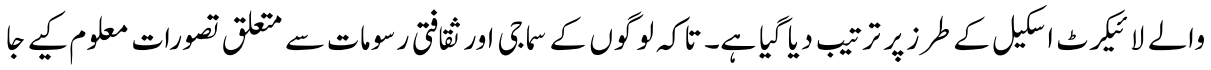

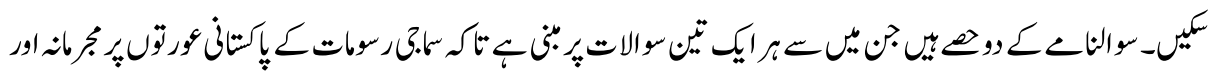

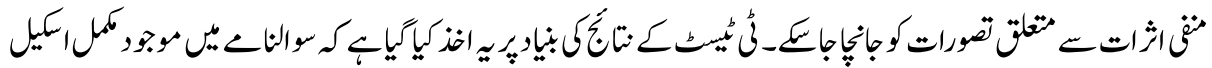

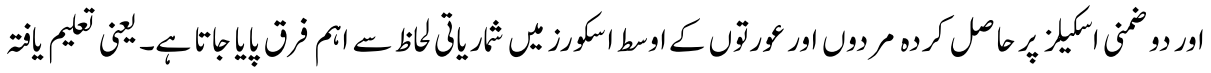

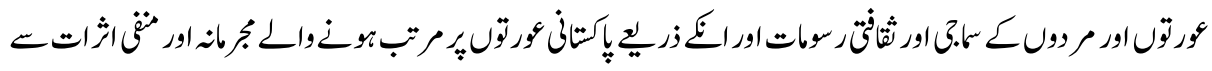

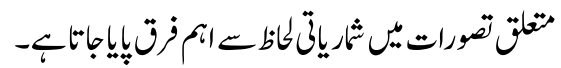

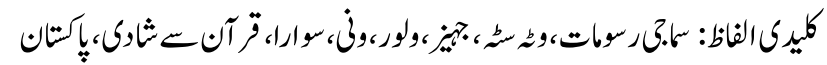

\section{Introduction}

Pakistani women have long been struggling for better status in several fields of life. They are still far behind the Pakistani men in terms of literacy, education, access to health facilities, workforce participation, economic empowerment, political representation, and ability to affect the legislative processes to ensure security for themselves. They have been assigned a lower status from within family to the state level. The broader traditional, social and cultural organization of Pakistani society results in this lower status of women. To understand the plight of Pakistani women and ensure effective solutions for improving the current situation, it is necessary to observe and analyze different aspects of social, cultural and gender order prevailing in the country. To start with the social and cultural arrangement within family and home, Pakistani women are mostly segregated in the private sphere of home, where they are living under the control and subordination of men family head patriarchs. The family head, dominantly men in Pakistan, possess the power to take decision in all matters. The men decides about the critical aspects of women's life, like education, marriage and mobility within family and outside in the public sphere.

Son preference is a common phenomenon in Pakistan. The implications of son preference, prevailing in Pakistani society, are affecting almost every Pakistani woman's life from birth to death. The implications include: less celebrated birth of girl child, unequal family investment in girls' and boys' education (considering investment on girls education as waste of resources as the girls have to soon move to their husbands' homes while the sons are the security of parents' old age), unpaid work of domestic chores' cultural assignment to girls and women, restricted mobility to the public sphere, thus resulting in less economic empowerment. Girls' less potential or prospects of becoming economically productive in paid work market combined with the universally practiced tradition of dowry to be given to girls at the time of marriage makes this situation more worse. Therefore, considering the girl child as an economic burden on family, traditionally 
parents prefer to get them married as soon as possible. Consequently, the traditions of child marriage and early marriages are commonly practiced in Pakistan, in general, and in rural Pakistan, in particular.

Marriage by choice, especially the expression of women's choice in the decision regarding her marriage still has attached stigma in traditional society of Pakistan. Any such attempt of marriage by choice, especially by any girl in tribal and feudal society, is considered as damage caused to the family honour. Beside the economic motives of land and property, the marriage by choice is another reason that leads to honour killing. Further, the institution of marriage is also utilized to make certain types of social or economic exchanges that result in disadvantage to the status of girl or women concerned. Families exchange women as brides in exchange marriages, mostly in biradri or cast systems, and justify this exchange as traditional and cultural practice. In tribal and feudal culture, women are exchanged in marriage as vani or swara to reach a peaceful settlement and security for the family men's life.

The public sphere is culturally assigned to men in Pakistani society. Pakistani men dominate the public sphere where they explore the educational, economic and political opportunities learn the skills, and establish social contacts. In this way men have more access to the resources that help them grow their human capital and get empower. On the other hand, Pakistani women's entry to this public sphere, their access to these resources and their opportunities to learn skills and grow their human capital are culturally conditioned in several ways (such as through non-permission from their family patriarchs, veiling/ Purdah, escorting by elder women or family men, religious interpretations regarding interaction with strangers are to name a few).

As less educated and less skillful with few social linkages (and whatever social linkages she has are defined in context of the men patriarch), Pakistani women remained far behind the Pakistani men in the competitive economic market. If few of them succeed in entering the workforce, they face harassment, remained less paid, segregated in lower tiers of official and professional hierarchy, and soon find themselves forced to choose between paid job or child care and family related responsibilities.

In this patriarchal social order women find less resource and opportunities to achieve the political and decision making power within family, in informal decision making councils (e.g. Jirgah) and in formal legislative forums at state level. Therefore, they remain unable to positively affect and change socially and culturally defined traditions and the formally formulated laws. The men remained the dominant decision making group from family to the state level. In this way several social and cultural practices remained practiced despite being unfavorable for women. 
There are certain social and cultural practices existing in Pakistan that are considered as harmful for women's right and status in Pakistani society. Jaheez (i.e. dowry), Watta Satta (i.e. exchange marriage), Walwar (i.e. bride price), Vani (i.e. exchanging women to settle disputes), Swara (i.e. giving women as blood money in case of murder), and Marriage with Quran (i.e. symbolic marriage of a woman with the holy book to curtail her right to marry a man) are to name a few. These socio-cultural practices are popularly considered as resulting in victimization of women in several ways by fostering crime against women, curbing their right to either marriage or marriage by choice, or by allowing exchange of them as commodity for benefit of their men patriarchs (Jilani \& Ahmed 2004). Therefore, these social practices are growingly perceived as crime against women in Pakistani society (Syed, Afzal \& Tabassum, 2015). The educated citizens are the segment of Pakistani society that is thought to be most vocal in condemning and declaring these anti women social practices. Throughout the last decade, the pressure of civil society and educated segment of society have exerted ample pressure on the state machinery and the legislatures to legally curb these social practices. A never precedent large number of women entering and participating in different tiers of the political system in last decade, inducted through gender quota system have also repeatedly raise these issues of women's victimization in the political and legislative forums (i.e. Local Governments, Provincial Assemblies, National Assembly and the Senate) (Syed \& Tabassum 2014, Tabassum 2016). The result was the formulation of a number of new laws and the amendments done to remove flaws from already existing legal provisions to protect women citizens (Weiss 2012, Tabassum 2016, Syed \& Tabassum 2014). Still the effective implementation of the new laws aimed at protecting and safeguarding women by curbing these harmful socio-cultural practices is a challenge faced by Pakistani society and law enforcing agencies.

Although, the way these social practices are being perceived and responded by all the segments of the society can be critical to its reinforced retention or elimination. The perceptions and the response of educated people towards these socio-cultural practices is critical in bringing legal change and their effective implementation. In Pakistani society, the existence of these social practices against women despite the existing laws is raising questions regarding their equal acceptance as condemnable practice by different segments of society (such as men and women, educated and uneducated segments and rural or urban geographical areas in all casts, and classes). To explore and study all the segments of a society for exploring differences in their perception regarding these social practices is beyond the limitations of this small scale independent research and available resources. Therefore, to keep the focus of this research narrow, this study aims to identify gender differentials in perceptions regarding these social practices among the most critical segment of population in bringing any social and ideological change in any society (i.e. educated people). 


\section{Literature Review}

A number of social and cultural customary practices are considered as causing harmful effects on women's status and rights in Pakistan. The crime and violence against Pakistani women also result from a variety of cultural practices (Jilani \& Ahmed 2004; Tabassum 2016). The available reports regarding situation of crime and violation against women in Pakistani society also include a variety of the crimes resulting from customary social practices (Azhar, 2012; Perveen, 2013). Several research studies have named and described these social practices as a prime source of violence and crime against women in Pakistan by negatively affecting their status and curtailing their rights in the name of culture. Tabassum, Tabassum and Afzal (2017) referred to dowry, watta satta, walwar, honour killing, marriage with Quran, Vani, Swara and Child marriage as harmful practices for women in Pakistan. Jilani and Ahmed (2004) have identified violence within the domestic sphere, killing in the name of honour, gifts given in the name of dowry at marriage, watta satta or exchange marriage, vani, early or child marriages, forced marriages, and marriage with Quran as some of these practices. Agha and Ahmed (2018:101) acknowledged that the social practices like watta satta (exchange marriage), dowry and bride price are contributing a great deal to women's disempowerment. Although, the list of such social practices is long, but this paper focuses on six social practices, most commonly identifies in literature, namely dowry, watta satta, walwar, vani/vani, swara, and marriage with Quran.

The most common and widely prevailing social practice of dowry, called "Jahez" is accepted as one culturally essential element of marriage arrangements across Pakistan entailing the potential for crime and violence against women. This social practice has been studied from a variety of historical, social, economic, and cultural perspectives by a large number of scholars and researchers (Ahmed, Hussain, Tariq, \& Raza, 2015; Ali, Árnadóttir, \& Kulane, 2013: 87; Ali, Krantz, \& Morgen, 2012: 579; Anjum, Malik, \& Khan, 1995; Gulzar, Nauman, Yahya, Ali, \& Yaqoob, 2012: 784; Shah, Arshad \& Qasim, 2016).

It connotes the property, money, and goods that a woman (i.e. bride) brings to her husband at the time of marriage (Anjum et al. 1995; Thompson 1997, 408). But the time has changed this cultural ritual from its original sense of a support to the new couple through gifts (Anjum et al. 1995; Gulzar et al. 2012, p.784) to a full flagged economic transaction including money, property, vehicles etc. (Ali et al. 2013, p.87). The transaction is associated with conditioning of brides respect and status in new home (Ali et al. 2012: 579; Anjum et al. 1995). It has become an economic burden on families and society. The result is mental, physical and financial agony for women and their parents (Gulzar et al. 2012, 784). It has the potential to result in violence against women in the forms of domestic violence and abuse by in laws, burning, killing, hanging (Ali et al. 
2013, pp.84-85; Ali et al. 2012: 579). Naved and Persson (2010) highlight that "dowry demand predicts the extent, frequency and severity of physical wife abuse... while no payment of dowry increases the likelihood of abuse, its frequency and severity" Gulzar et al. (2012, p.785) aptly suggest that dowry system should be banned in Pakistan.

Watta satta, exchange marriage, is simply an exchange of bride between two families in exchange of each other (Baghal, Khaskhely, Sheikh, \& Sheikh 2016: 104; Bhutta, Warraich, Bhutta, Bhutta \& Ali 2015:166; Riaz, Mannan, \& Malik 2016). It has been claimed as accounting one third of all marriages in rural Pakistan (Jacoby \& Mansuri $2010,1804)$. Some of the researches have advocated the purpose of this type of marriage as social security for women by establishing the reciprocal conditioning of the grooms behaviour and violence against brides, through a tit for tat treatment of both exchanged brides in two houses (Jacoby \& Mansuri, 2010; Zaman, 2012:11). But still this benefit of social security equally entails the potential of reciprocal violence to each of the women, in case anything went wrong with anyone of them (Jilani \& Ahmed 2004, 194). This type of marriages is used to control and maintain a balance of power between families and the couples (Naveed \& Butt, 2015: 167). The men's behaviour is conditioned through good or abusive treatment extended to his blood relative bride involved in exchange and living in other party's home (Jacoby \& Mansuri, 2010, 1806; Zaman 2013; Zaman, Zakar, \& Sharif 2014). Therefore, it is considered as a double edged sword that cuts both ways (Bhutta et al. 2015: 167; Jacoby \& Mansuri, 2010, 1813). In both cases either providing social safety or creating violence, this type of marriage limits women's right of marriage by her free choice (Tabassum et al. 2017: 117; Zaman, 2012:11). Soomro and her fellows (2013) discuss the effects of exchange marriages including domestic violence, estrangement, depression and violation of rights. This type of exchange also has the potential for exchange of children, mostly girls, in marriage, even before or after birth (Bagahl et al. 2016: 104 -107; Naveed \& Butt, 2015: 167). Similarly, walwar is another social practice that leads to selling of girls in marriage (Jilani \& Ahmed 2004, 194). It is a source of violating women's right of marriage with free consent. It victimized young girls who are sold for money under this custom.

The exchange of women and girls is also used for the settlement of disputes among tribes, families and individuals (Abbas \& Riaz 2013). This practice is existing in all regions of Pakistan with different names: in Khyber Pakhtoonkhwa as Swara, in Balochistan as Irjaee, in Sindh as Sung-Chatti and in Punjab as Vani (Abbas \& Riaz 2013, 174). The girls are given in exchange of the damage caused to human, honour or finances among tribes or clans (Abbas \& Riaz 2013). The murder committed by a man family member can be compensated by giving off a young girl as blood money (Jilani \& Ahmed 2004, 195; Zuhur 2005). This practice entails a humiliating life for the women given off and violates their rights of free life. 
There is ample evidence of this evil cultural practice existing in district Swat, Kohistan (Hanan, Shah, \& Khan 2017a; 2017b; 2017c). Hanan and his fellows (2017a; 2017b) have conducted a research study on this issue with 205 swara victims, their parents and brothers, and blood relatives. Hannan and others (2017a) claimed that 336 cases of Swara had been reported from the year 2002 to the year 2014. Studying the cultural aspect of dispute settlement through giving off women as compensation, they found that "Swara had cultural endorsement despite of no any feelings of honor rather getting ashamed of it were found instrumental factors in women as compensation practices" (Hannan et al. 2017:1). Similarly, Munir \& Akhtar (2014:7) highlight that the tradition of vani is linked with blood feuds among tribes where women are forcibly married to the members of victim tribe as a compensation for settling the said dispute. In their research Munir \& Akhtar (2014) elaborately explained vani in historical context and with reports of new incidence declaring it un-Islamic and un-lawful.

Marriage with Quran is another customary practice in Sindh and northern Punjab (Mumtaz \& Nosheen (2014:108). This evil practice is violating women's rights of marriage and inheritance but mostly done very secretly and never reported to law enforcing agencies. It is also known as Haq Bakshwan (Jilani \& Ahmed, 2004, p.195). In this custom, the women are considered married to Quran. The two reasons for practicing this evil custom are identified as if parents lack sufficient money to get their daughter married and keep the land and property within family (Iqbal 2007; Jilani \& Ahmed 2004, 195; Mumtaz \& Nosheen 2014:108). This practice makes women withdraw her right to marry a man (Mumtaz \& Nosheen 2014:108; Tabassum et al. 2017: p.117).

\section{Gender Wise Differences in Perception and Response to these Social Practices}

The question arises that does women have a different perception of the same sociocultural practice than that of men. Majority of the literature available is silent in this regard. Whatever knowledge is available is about people's perceptions in general, not on the gender difference in particular. Syed, Afzal, and Tabassum (2015:34) highlight that anti-women social practices are perceived as an important reason behind persisting crime against women in Pakistan by $82 \%$ of the research participants of their research.

Ahmed, Hussain, Tariq and Raza (2015) show that the respondents agree that dowry ensures respect from husbands (i.e. 68\% agree), dowry ensures husbands giving honour to wives (i.e. 64\% agreed), dowry ensures husband's support to wife in family disputes (i.e. 78\% agreed), dowry is crucial for success of marital life (i.e. 86\% agreed). Tabassum, Tabassum and Afzal (2017: 120) highlight that 76\% of the research participants perceived dowry as having potential for resulting in crime against women. The same research further identifies that $92 \%$ of the research participants perceived the same for watta satta, $83 \%$ for walwar, $93 \%$ for vani, $90 \%$ for swara and $90 \%$ considering Marriage 
with quran as having potential for resulting in crime against women. Hannan et al. (2017), discussing swara and exchange of women, did not pay any attention to the gender difference in perceptions in this regard. The point is that if men have differently perceived the potential of socio-cultural practices than women, this may lead to their use of patriarchal power and control to foster and practice such practices on and on. There is need for research to understand and explore this difference between men and women's perception regarding such harmful social and cultural practices.

\section{Objectives}

- To identify the difference among educated men and women's perception regarding certain social and cultural practices (i.e. dowry, watta Satta, walwar, marriage with Quran, vani, and swara) as victimization of and crime against women in Pakistan.

- To identify the difference in perception of educated men and women about the potential of certain social practices (i.e. dowry, walwar, watta satta) as resulting in victimization of women in Pakistan.

- To identify the difference in perceptions of educated men and women about certain social practices (i.e. vani, swara, marriage with Quran) as crime against women in Pakistani society.

\section{Hypotheses}

H1: The mean of total score of women on the scale of "Perceptions regarding Social Practices (SP)" is significantly higher as compared to the mean of total score of men.

H2: The mean score of women on sub-scale of "Social practices perceived as resulting in victimization of women in Pakistan (SPV)" is significantly higher as compared to the mean score of men.

H3: The mean score of women on sub-scale of "Social practices perceived as crime against women in Pakistan (SPC)" is significantly higher as compared to the mean score of men.

\section{Significance of the Research Study}

The general popular perception regarding certain social practices (i.e. dowry, Walwar, Watta, Satta, Vani, Swara, marriage with Quran) are of non acceptance, then the question arises that why these victimizing social practices are still existing and being practiced in 
different sections of Pakistani society. Are all the stake holders (e.g. men and women) are having the same perception about harmful nature of these social practices in Pakistan? There is not much data available to showing the difference of perception regarding these social practices and their harmful potential among men and women in Pakistan. Therefore, this research is aimed to fill this knowledge gaps in existing literature on gender difference in perceptions regarding certain harmful social practices and their potential for victimization of women in Pakistan.

\section{Research Methodology}

This research study is designed as an exploratory cross-sectional research with quantitative approach to data collection and analysis. The unit of analysis is educated individual men and women. The population of the study comprises of educated men and women of Sindh. Random sampling method was used to select a representative sample for data collection. Total 384 educated men and women from across the Sindh province were selected for data collection. Survey method of data collection was adopted.

The research tool used for collecting data was comprises of a questionnaire developed by the researcher including a six items scale with five point Likert scale response categories for assessing research participants' perceptions regarding social practices. The complete six item scale named "perceptions regarding social practices (SP)" is divided into two sub scales (each comprising three items) namely "Social practices as crime against women (SPC)" and "Social practices resulting in victimization of women (SPV)".

After data entered in computer and cleaning using Excel and SPSS 21, total 347 cases were retained including 124 (i.e. 35\%) men respondents and 223 (i.e. 64.3\%) women respondents. Factor analysis showed that all the six items were finely extracted on two factors as already designed for with factor loadings for each item ranges between 0.596 to 0.842. The Cronbach's Alpha for the complete scale of "Perceptions regarding social practices (SP)" (6 items) is 0.7418 , for the sub scale of "Social practices as crime against women (SPC)" (i.e. Factor 1, three items) is 0.7191 , and for sub scale of "Social practices as victimization for women (SPV) (i.e. Factor 2, three items) is 0.6546 . The hypotheses were tested by applying t-test on scores of the research participants acquired on the three scales (i.e. SP, SPV, SPC) to know the gender differences in perception of educated people regarding social practices. 


\section{Data Presentations and Discussion}

According to the objectives of this research study, the data was analyzed by applying ttest to identify differences in men and women's mean scores on the scale of "Perception regarding social practices (SP)" (i.e. Dowry, Walwar, Watta Satta, Marriage with Quran, Vani, Swara as resulting in crime and victimization against women in Pakistan. The results of the statistical test show that the mean score of the men research participants $(\mathrm{N}=124)$ on the six items scale of SP is 24.7258 with $d f=4.0290$, standard error mean as 0.3618 . The mean score of women research participant $(\mathrm{N}=223)$ on the same six items scale of SP is 26.3812 with $d f=2.9778$, standard error mean 0.1994 .

Table: 1

Group Statistics

\begin{tabular}{|l|c|c|c|c|c|}
\hline & Gender & N & Mean & $\begin{array}{c}\text { Std. } \\
\text { Deviation }\end{array}$ & $\begin{array}{c}\text { Std. Error } \\
\text { Mean }\end{array}$ \\
\hline $\begin{array}{l}\text { SP (Perceptions regarding } \\
\text { social practices) }\end{array}$ & Male & 124 & 24.7258 & 4.02904 & .36182 \\
\hline & Female & 223 & 26.3812 & 2.97785 & .19941 \\
\hline
\end{tabular}

Table: 2

Independent Samples Test

\begin{tabular}{|c|c|c|c|c|c|c|c|c|c|c|}
\hline & \multicolumn{7}{|c|}{$\begin{array}{l}\text { Levene's Test } \\
\text { for Equality of } \\
\text { Variances }\end{array}$} & \multicolumn{7}{|c|}{ t-test for Equality of Means } \\
\hline & $\mathrm{F}$ & Sig. & $\mathrm{T}$ & $\mathrm{Df}$ & $\begin{array}{l}\text { Sig. (2- } \\
\text { tailed) }\end{array}$ & $\begin{array}{c}\text { Mean } \\
\text { Difference }\end{array}$ & $\begin{array}{c}\text { Std. Error } \\
\text { Difference }\end{array}$ & $\begin{array}{c}95 \% \text { Confidence } \\
\text { Interval of the } \\
\text { Difference }\end{array}$ \\
\hline & & & & & & & & & Lower & Upper \\
\hline SP & $\begin{array}{l}\text { Equal } \\
\text { variances } \\
\text { assumed }\end{array}$ & 18.381 & .000 & -4.359 & 345 & .000 & -1.6554 & .37978 & -2.40233 & -.90839 \\
\hline & $\begin{array}{l}\text { Equal } \\
\text { variances not } \\
\text { assumed }\end{array}$ & & & -4.007 & 198.904 & .000 & -1.6554 & .41313 & -2.47004 & -.84068 \\
\hline
\end{tabular}

The t-test results show the $F=18.381$ and $p$ value $<001$. As the value of $p$ is less than 0.05 , it shows that the variance between men and women's score on SP scale is not equal. Therefore, unequal variance can be assumed. As the F-Statistics show that the homogeneity of variance cannot be assumed for men and women's perception regarding social practices, the $t$-test results appear as following $t=-4.007, \mathrm{df}=198.9, p<0.001$. Hence the difference between men and women's mean scores on SP scale for perception 
regarding social practices is significant at $p<0.001$. Therefore, it is inferred that the mean of total score of women on the SP scale of "Perceptions regarding Social Practices (SP)" is statistically significantly different from the mean of total score of men acquired on the same scale.

Still the nature of difference is needed to be ascertained. Therefore, to identify the nature or direction of the difference between men and women's mean score on the same scale, the respective mean scores of the men and women participants as stated in Table 1 were consulted. The mean score of women is (26.3812) as compared to the means score of men as (24.7258). It shows that women are statistically significantly scoring higher on SP scale of perceptions regarding social practices and their potential as crime and victimization against women in Pakistan as compared to the mean score acquired by men on the same SP scale. Therefore, the alternative hypothesis (H1) stating that the mean of total score of women on the SP scale is statistically significantly higher than the mean of total score of men acquired on the same scale is accepted. It can be safely inferred that educated women in Sindh are more strongly perceiving, thus condemning, the six social practices focused in this research as persisting sources of crime and victimization against Pakistani women as compared to the educated men in Sindh.

The t-test was applied to identify any gender specific differences in perception regarding the potential of social practices (i.e. Dowry, Watta Satta, and Walwar) for victimization of women in Pakistan as assessed on the sub scale SPV. The results of the statistical test show that the mean score of the men research participants $(\mathrm{N}=124)$ on the three item sub scale of SPV is 11.9113 with $d f=2.472$, and standard error mean as 0.222 . The mean score of women research participant $(\mathrm{N}=223)$ on the same three item sub scale of SPV is 12.9103 with $d f=1.8914$, and standard error mean as 0.1266 .

Table: 3

Group Statistics

\begin{tabular}{|l|c|c|c|c|c|}
\hline & Gender & $\mathrm{N}$ & Mean & $\begin{array}{c}\text { Std. } \\
\text { Deviation }\end{array}$ & $\begin{array}{c}\text { Std. Error } \\
\text { Mean }\end{array}$ \\
\hline $\begin{array}{l}\text { SPV (Social practices resulting in } \\
\text { victimization of women) }\end{array}$ & Male & 124 & 11.9113 & 2.47265 & .22205 \\
\cline { 2 - 6 } & Female & 223 & 12.9103 & 1.89143 & .12666 \\
\hline
\end{tabular}


Gender Differentials in Educated People's Perceptions Regarding Anti Women Social Practices in Pakistan

Table: 4

Independent Samples Test

\begin{tabular}{|c|c|c|c|c|c|c|c|c|c|c|}
\hline & & \multicolumn{2}{|c|}{$\begin{array}{c}\text { Levene's Test } \\
\text { for Equality of } \\
\text { Variances } \\
\end{array}$} & \multicolumn{7}{|c|}{ t-test for Equality of Means } \\
\hline & & \multirow[t]{2}{*}{$\mathrm{F}$} & \multirow[t]{2}{*}{ Sig. } & \multirow[t]{2}{*}{$\mathrm{T}$} & \multirow[t]{2}{*}{ Df } & \multirow[t]{2}{*}{$\begin{array}{l}\text { Sig. (2- } \\
\text { tailed) }\end{array}$} & \multirow[t]{2}{*}{$\begin{array}{c}\text { Mean } \\
\text { Difference }\end{array}$} & \multirow[t]{2}{*}{$\begin{array}{l}\text { Std. Error } \\
\text { Difference }\end{array}$} & \multicolumn{2}{|c|}{$\begin{array}{l}95 \% \text { Confidence } \\
\text { Interval of the } \\
\text { Difference }\end{array}$} \\
\hline & & & & & & & & & Lower & Upper \\
\hline \multirow[t]{2}{*}{ SPV } & $\begin{array}{l}\text { Equal } \\
\text { variances } \\
\text { assumed } \\
\end{array}$ & 12.431 & .000 & -4.213 & 345 & .000 & -.9990 & .23715 & -1.46547 & -.53258 \\
\hline & $\begin{array}{l}\text { Equal } \\
\text { variances not } \\
\text { assumed }\end{array}$ & & & -3.908 & 204.090 & .000 & -.9990 & .25563 & -1.50305 & -.49500 \\
\hline
\end{tabular}

The t-test results show the $F=12.431$ and $p$ value $<.001$. As the value of $p$ is less than 0.05 , it shows that the variance between mean scores acquired by men and women research participants on SPV sub scale is not equal. Therefore, unequal variance can be assumed. As the $F$-Statistics show that the homogeneity of variance cannot be assumed for men and women's perception regarding the potential of social practices (of dowry, watta satta, Walwar) for victimization of women in Pakistan, the $t$-test results appear as following: $t=-3.908, \mathrm{df}=204, p<0.001$. Hence the difference between men and women's means scores on scale for perception regarding potential of social practices for victimization of women is significant at $p<0.001$. It is inferred that the mean score of women on sub-scale of "Social practices resulting in victimization of women in Pakistan (SPV)" is significantly different as compared to the mean score of men.

Still the nature of difference is needed to be ascertained. Therefore, to identify the nature or direction of the difference between men and women's mean score on the same scale of SPV, the respective mean scores of the men and women participants as stated above were consulted. The mean score of women is (12.9103) as compared to the means score of men as (11.9113) on the SPV sub scale. It shows that women are statistically significantly scoring higher on SPV sub scale, used to explore the perceptions about the victimizing potential of certain social practices (of dowry, Watta Satta, and Walwar) for Pakistani women, as compared to the mean score acquired by men on the same sub scale SPV. Therefore, the alternative hypothesis $(\mathrm{H} 2)$, stating that the mean score of women on sub-scale of "Social practices perceived as resulting in victimization of women in Pakistan (SPV)" is significantly higher as compared to the mean score of men is accepted. It can be inferred that educated women in Sindh are more strongly perceiving, thus condemning, the three social practices of dowry, watta 
satta, and Walwar as giving rise to victimization of Pakistani women as compared to the educated men in Sindh.

\section{Gender Differences in Perceptions about Social Practices as Crime}

The t-test was again applied to identify any gender specific difference in men and women's mean scores on the scale of perception regarding social practices (i.e. Marriage with Quran, Vani, Swara) as crime against Pakistani women, as assessed on the scale SPC. The results of the statistical test show that the mean score of the men research participants $(\mathrm{N}=124)$ on the three items sub scale of SPC is 12.8145 with $d f=2.328$, standard error mean as 0.2090 . The mean score of women research participant $(\mathrm{N}=223)$ on the same three item sub scale of SPC is 13.4709 with $d f=1.6543$, standard error mean as 0.1107 .

Table: 5

Group Statistics

\begin{tabular}{|l|c|c|c|c|c|}
\hline & Gender & $\mathrm{N}$ & Mean & $\begin{array}{c}\text { Std. } \\
\text { Deviation }\end{array}$ & $\begin{array}{c}\text { Std. Error } \\
\text { Mean }\end{array}$ \\
\hline $\begin{array}{l}\text { SPC (Social practices as crime } \\
\text { against women) }\end{array}$ & Male & 124 & 12.8145 & 2.32822 & .20908 \\
\cline { 2 - 6 } & Female & 223 & 13.4709 & 1.65432 & .11078 \\
\hline
\end{tabular}

Table: 6

Independent Samples Test

\begin{tabular}{|c|c|c|c|c|c|c|c|c|c|c|}
\hline & & \multicolumn{2}{|c|}{$\begin{array}{c}\text { Levene's Test } \\
\text { for Equality of } \\
\text { Variances } \\
\end{array}$} & \multicolumn{7}{|c|}{ t-test for Equality of Means } \\
\hline & & $\mathrm{F}$ & Sig. & \multirow[t]{2}{*}{$\mathrm{T}$} & \multirow[t]{2}{*}{ Df } & \multirow[t]{2}{*}{$\begin{array}{l}\text { Sig. (2- } \\
\text { tailed) }\end{array}$} & \multirow[t]{2}{*}{$\begin{array}{c}\text { Mean } \\
\text { Difference }\end{array}$} & \multirow[t]{2}{*}{$\begin{array}{l}\text { Std. Error } \\
\text { Difference }\end{array}$} & \multicolumn{2}{|c|}{$\begin{array}{l}95 \% \text { Confidence } \\
\text { Interval of the } \\
\text { Difference }\end{array}$} \\
\hline & & & & & & & & & Lower & Upper \\
\hline SPC & $\begin{array}{l}\text { Equal } \\
\text { variances } \\
\text { assumed }\end{array}$ & 12.643 & .000 & -3.049 & 345 & .002 & -.6563 & .21529 & -1.07978 & -.23289 \\
\hline & $\begin{array}{l}\text { Equal } \\
\text { variances not } \\
\text { assumed }\end{array}$ & & & -2.774 & 193.315 & .006 & -.6563 & .23662 & -1.12302 & -.18966 \\
\hline
\end{tabular}

The t-test results show the $F=12.643$ and $p$ value $<001$. As the value of $\operatorname{Sig} .(p)$ is less than 0.05 , it shows that the variance between men and women's mean score acquired on sub scale of SPC are not equal, therefore, unequal variance can be assumed. As the $F$ Statistics show that the homogeneity of variance cannot be assumed for men and women's perception regarding social practices (i.e. Marriage with Quran, Vani, Swara) as 
crime against Pakistani women, the $t$-test results appear as following $t=-2.774, \mathrm{df}=193.3$, $p<0.01$. Hence, the difference between men and women's means scores acquired on the sub scale SPC for perception regarding social practices (of marriage with Quran, Vani, Swara) as crime against women is statistically significant at $p<0.01$. Therefore, it is inferred that the mean score of women on sub-scale of "Social practices perceived as crime against women (SPC)" is significantly different as compared to the mean score of men on the same sub scale.

The difference in means scores is established, but still the nature or the direction of the difference is needed to be ascertained. Therefore, to identify the nature or direction of the difference between men and women's mean score on the same scale of SPC, the respective mean scores of the men and women participants as stated above were once again consulted. The mean score of women is (13.4709) as compared to the means score of men as (12.8145) on the SPC sub scale. It shows that women are statistically significantly scoring higher on SPC sub scale, used to explore the perceptions about certain social practices (marriage with Quran, Vani, Swara) as crime against Pakistani women, as compared to the mean score acquired by men on the same sub scale SPC. The results show that women are statistically significantly scoring higher on scale of certain social practices considered as crime against Pakistani women. Therefore, the alternative hypothesis $(\mathrm{H} 3)$ stating that the mean score of women on sub-scale of "Social practices perceived as crime against women (SPC)" is significantly higher as compared to the mean score of men on the same sub scale is accepted. It can be inferred that educated women in Sindh are more strongly perceiving, thus condemning, the three social practices of marriage with Quran, Vani, and Swara as crime against Pakistani women as compared to the educated men in Sindh.

\section{Conclusions}

The research study explored the gender differentials in the perceptions of educated people regarding certain socio-cultural practices prevailing in Pakistani society that are considered as negatively effecting Pakistani women. The results of the data analysis show that educated women are scoring higher on the scale of "Perceptions regarding social practices (SP)" and the two sub scales of "Social practices resulting in victimization of women (SPV)" and "Social practices as crime against women (SPC)" as compared to men. It shows statistically significant difference in the perception of men and women on these three scales. On the one hand, as men are scoring low on all the three scales, it shows that men are less considering these social practices as victimizing and fostering crime against women. On the other hand, as women are scoring higher on three scales, it means that women are more considering these social practices as harmful for women. 
The study only includes the perceptions of educated peoples of Sindh. The future research may include other groups including illiterate and less educated people. This research only focuses on gender related difference in perceptions. The future research may focus on differences in perceptions regarding these social practices held by rural and urban people, literate and illiterate people, people belonging to different economic strata, etc.

\section{References}

Abbas, M. Z. \& Riaz, S. (2013). Legal Protections Provided Under Pakistani Law against Anti-Women Practices: Implementation Gaps between Theory and Practice. The Dialogue, vol.8:2, pp.172-185.

Agha, N. \& Ahmed, Z. (2018). Prevalence and Nature of Violence against Women in Pakistan: A Six-month Content Analysis of a Pakistani Newspaper. Pakistan Journal of Criminology, vol.10:1, pp.100-120.

Ahmad, N., Hussain, A., Tariq, M. S. \& Raza, M. A. (2015). Role of Dowry in Successful Marital Life: A Case Study of District Dera Ghazi Khan, Pakistan. Kuwait Chapter of Arabian Journal of Business and Management Review, vol.4:5, pp.62-72.

Ali, T. S., Árnadóttir, G. \& Kulane, A. (2013). Dowry Practices and their Negative Consequences from a Female Perspective in Karachi, Pakistan: A Qualitative Study. Health, vol.5:7, pp.84-91.

Ali, T. S., Krantz, G. \& Mogren, I. (2012). Violence Permeating Daily Life: A Qualitative Study Investigating Perspectives on Violence among Women in Karachi, Pakistan. International Journal of Women's Health, vol.4, pp.577-585.

Anjum, T., Malik, N. H. \& Khan, S. A. (1995). A Study of Dowry and Marriage Arrangements in a Rural Area of District Faisalabad. Pakistan Journal of Agricultural Sciences, vol.32:4, pp.298-299.

Azhar, N. (2012). Violence against Women in Pakistan: A Qualitative Review of Statistics for 2011. Islamabad: Aurat Publication and Information Service Foundation.

Bagahl, G. U., Khaskhelly, N., Shaikh, E. K. Z. \& Sheikh, M. A. (2016). Empirical Analytical Study on Socio-Economic Factor of Early Marriages: A Case Study of Badin District, Sindh, Pakistan. The Government: Research Journal of Political Science, vol.V, pp.101-116. 
Bhutta, R. N., Warich, I. A., Bhutta, A., Bhutta, N. I. \& Ali, M. (2015). Dynamics of Watta Satta Marriages in Rural Areas of Southern Punjab Pakistan. Open Journal of Social Sciences, vol.3, pp.166-178.

Gulzar, S., Nauman, M., Yahya, F., Ali, S. \& Yaqoob, M. (2012). Dowry System in Pakistan. Asian Economic and Financial Review, vol.2:7, pp.784-794.

Hanan, F., Shah, M. \& Khan, N. (2017a). Cultural Involvement in Dispute Settlement Through Women as Compensation in District Swat Kohistan-Pakistan. Research on Humanities and Social Sciences, vol.7:21, pp.1-8.

Hanan, F., Shah, M. \& Khan, N. (2017b). Dispute Settlement in Pukhtoon Culture through Women as Compensation in Tehsil Kalam Khyber Pakhtukhwa-Pakistan. Journal of Culture, Society and Development, vol.36, pp.12-29.

Hanan, F., Shah, M. \& Khan, N. (2017c). Religious Misconception Leads to Various Practices of Women as Compensation in Dispute Settlement in Khyber Pakhtukhwa. Journal of Philosophy, Culture and Religion, 34.

Iqbal, N. (2007) Legal Pluralism in Pakistan and its Implications on Women's Rights. In Bennett, J. (Ed.) Scratching the Surface: Democracy, Traditions, Gender (pp. 101-117). Pakistan: Heinrich Böll Foundation.

Jacoby, H. G., \& Mansuri, G. (2010). Watta Satta: Bride Exchange and Women's Welfare in Rural Pakistan. American Economic Review, vol.100, pp.1804-1825.

Jilani, H. \& Ahmed, E. M. (2004). Violence Against Women: The Legal System and Institutional Responses in Pakistan. In S. Goonesekere (Ed.), Violence Law \& Women's Rights in South Asia (pp. 148-206). New Delhi: Sage Publication.

Mumtaz, M. \& Nosheen. (2014). Analytical Study of Available Legal Protection To Women Against Prevailing Evil Customs in Pakistan. Sci-Afric Journal of Scientific Issues, Research and Essays, vol.2:2, pp.108-110.

Munir, A. \& Akhtar, N. (2014). A Social Custom "Vani": Introduction and Critical Analysis. VFAST Transactions on Education and Social Sciences, vol.3:2, pp.07-10.

Naved, R. T. \& Persson, L. A. (2010). Dowry and Spousal Physical Violence Against Women in Bangladesh. Journal of Family Issues, vol.XX:X, pp.1-27. 
Naveed, S. \& Butt, K. M. (2015). Causes and Consequences of Child Marriages in South Asia: Pakistan's Perspective. South Asian Studies: A Research Journal of South Asian Studies, vol.30:2, pp.161-175.

Perveen, R. (2013). Beyond Denial: Violence against Women in Pakistan-A Qualitative Review of Reported Incidents (January-December 2012). Islamabad: Aurat Publication and Information Service Foundation.

Riaz, H. F., Mannan, S. \& Malik, S. (2016). Consanguinity and Its Socio-Biological Parameters in Rahim Yar Khan District, Southern Punjab, Pakistan. Journal of Health, Population and Nutrition, vol.35:14, pp.1-11.

Shah, M. A. A., Arshad, S. \& Qasim, H. (2016). A Statistical Study of Dowry Determinants in Urban and Rural Areas of Punjab, Pakistan. Journal for Studies in Management and Planning, vol.2:3, pp.132-137.

Soomro, S., Lalani, F. \& Qureshi, M. B. (2013). Demerits of Exchange Marriages in Sindh. International Research Journal of Arts \& Humanities (IRJAH), vol.41:41, pp.255-270.

Syed, N. T. \& Tabassum, H. (2014). Women's Political Participation in Pakistan. Pakistan Journal of Gender Studies, vol.8, pp.131-143.

Syed, N. T., Afzal, T. \& Tabassum, H. (2015). Educated People's Perceptions Regarding Causes of Persisting Crime Against Women in Pakistani Society. Journal of Independent Studies and Research-Management, Social Sciences and Economics, vol.13:1, pp.29-43.

Tabassum, N. (2016). Women in Pakistan: Status in Socio-Cultural and Politico-Legal Domains. Islamabad: Higher Education Commission of Pakistan.

Tabassum, N., Tabassum, H. \& Afzal, T. (2017). Relationship between Patriarchy and Customary Social Practices Affecting Women's Life in Pakistan. Pakistan Journal of Gender Studies, vol.14, pp.111-128.

Thompson, D. (1997). The Concise Oxford Dictionary. 9th. London: BCA.

Weiss, A. M. (2012). Moving Forward with the Legal Empowerment of Women in Pakistan. United States Institute of Peace, USA. 
Zaman, M. (2012). Exchange Marriage System and Muslim Family Laws in Pakistan. Pakistan Journal of History and Culture, vol.XXXIII:1, pp.1-12.

Zaman, M. (2013). Exchange Marriages in a Community of Pakistan: Adequate Social Exchange. The Family Journal: Counseling and Therapy for Couples and Families, vol.22:1, pp.69-77.

Zaman, M., Zakar, M. Z. \& Sharif, A. (2014). The Exchange-Marriage System, Traditional Gender Roles and Obscured Transformations in A Community of Pakistan: The Interplay Between Structure, Agency and Social Change. Pakistan Journal of Gender Studies, vol.9, pp.51-72.

Zuhur, S. (2005). Gender, Sexuality and the Criminal Laws in the Middle East and North Africa: A Comparative Study. Istanbul, Turkey: Women for Women's Human Rights-New Ways.

Dr. Naima Tabassum is an Associate Professor in the Area Study Center, University of Sindh, Jamshoro.

Ms. Tabassum Afzal is an Assistant Professor in the Department of Education, University of Karachi.

Ms. Huma Tabassum is an Assistant Professor in the Government Degree College Latifabad No. 08, Latifabad, Hyderabad. 